\title{
Self-sacrifice for a cause: The role of ideas and beliefs in motivating human conflict
}

\author{
Jeremy Ginges and Crystal Shackleford \\ New School for Social Research, New York, NY 10011.
}

Corresponding author: Jeremy ginges. Email: gingesj@newschool.edu

Citation: Ginges, J. Shackleford, C. (in press). Self sacrifice for a cause: The role of ideas and beliefs in motivating human conflict. Behavioral and Brain Sciences.

This pre-print may not exactly replicate the final version published in the jounral. It is not the copy of record 
Abstract: The role of ideas and beliefs is generally underplayed in Whitehouse's account.

However, just as people may feel that their identity is fused with a collective, they may also feel that their identity is fused with an idea (god, history, justice), which can motivate the same type of behaviors that Whitehouse seeks to explain. 
In a fascinating paper, Whitehouse makes perhaps the strongest case yet for the importance of identity fusion in motivating self-sacrificial behavior of individuals in human conflict. His thesis is that when individual identities are "fused" with the group, a threat to the group is experienced as a threat to self, thereby motivating self-sacrificial behavior such as suicide attacks.

Whitehouse's argument gives a primary role to identify fusion, and explicitly discounts the theoretical relevance of belief. Here, we argue for the importance of beliefs in motivating much human conflict and sacrifice in the name of the cause.

How can we understand the type of violent self-sacrifice that occurs so frequently in human conflict? Identity fusion seems important, but the fact that an individual is fused to a common identity tells us little about what types of behaviors he or she will carry out for the collective under threat. To explain this, we need to understand how people reason about ideas and beliefs which motivate specific behaviors. Many young groups of Germans in the 1940s were fused with each other, but few sacrificed their lives to oppose the Nazi regime, as was the case with the White Rose non-violent resistance group (Dumbach \& Newborn 2017). People who feel fused with a group in the face of a threat, may kill and die, but they may also decide to negotiate and compromise to end intergroup conflict, or they might offer non-violent resistance. These different modes of behaviors are tied to shared beliefs about the nature of their group, the nature of morality, and intergroup relations (Kruglanski et al.,2013; Rai \& Fiske 2011). Ehud Sprinzak described the way the changing nature of such beliefs correlates with changing collective behavior, from non-violent protest to political violence (Sprinzak1990). Indeed, the stated aim of much political violence is to change the way an already-fused collective views itself, making it ready for rebellion (Ginges 1997). 
Whitehouse's argument is that threat translates identity fusion into action. While this seems likely to be true, threats are more than material in nature. Often, people will be motivated to sacrifice themselves because of threats not to material survival, but to an abstract idea (Bélanger et al. 2014). Shared ideas and beliefs about the world help us to coordinate and cooperate. We use shared beliefs to define self (Atran \& Ginges 2012), and tell stories to promote within-group cooperation (Smith et al. 2017). Such beliefs can become so cherished that they acquire transcendental meaning or sacredness, for which people are willing to sacrifice their lives, their family, or their community (Ginges et al. 2007; Ginges et al. 2011). Threats to sacred values can motivate non-instrumentally rational commitments to violent action (Ginges \& Atran 2011). We die for the group, but we also die for ideas.

A complete explanation of self-sacrifice in human conflict needs to consider the way people conceptualize self relative to collective identities, but also the way they conceptualize self relative to other abstract beliefs. Beliefs are often markers for collective identity, but they cannot be reduced to this. The opposite can be true: Groups are formed because of common beliefs, and a group may split because of different beliefs among its members (Sprinzak 1990). Moreover, sometimes self-sacrifice is carried out for a belief at the expense of a group one feels fused with. Some years ago, one of us, in the course of carrying out fieldwork with Jewish Israelis living in the West Bank ("settlers"), was told by interviewees that they would refuse to leave their land and homes if the government or even their community voted to leave, because the value of the land trumped all else. In studies with frontline combatants in Iraq, and Spanish civilians, Gomez et al. (2017), show that (a) when given a choice between an important sacred value and a group 
they feel fused with, frontline combatants are more likely to choose the value over the group, and (b) among frontline combatants, willingness to choose the value over the group predicts willingness to sacrifice in the conflict. Of course, the opposite will also sometimes occur, where people might sacrifice a cherished value for a cherished group.

Why do individual humans sacrifice their own lives, and those of others, for non-kin? One possibility is that neither sacred values nor fused identities have primary roles in facilitating the types of self-sacrifice Whitehouse is seeking to explain. Rather, both are important. Humans frequently sacrifice all in the name of abstract causes. It is not the nature of the cause that is important. The cause may be the group or another abstract belief like kurdeity, sacred land, or god. Regardless, it seems likely that a "visceral sense of oneness" between self and cause, is an important psychological mechanism that facilitates self-sacrifice.

\section{References}

Atran, S. \& Ginges, J. (2012) Religious and sacred imperatives in human conflict. Science 336(6083):855-57.

Bélanger, J. J., Caouette, J., Sharvit, K. \& Dugas, M. (2014) The psychology of martyrdom: Making the ultimate sacrifice in the name of a cause. Journal of Personality and Social Psychology 107(3):494-515.

Dumbach, A. \& Newborn, J. (2017) Sophie Scholl and the white rose. Oneworld Publications.

Ginges, J. (1997) Deterring the terrorist: A psychological evaluation of different strategies for deterring terrorism. Terrorism and Political Violence 9(1):170-185. 
Ginges, J. \& Atran, S. (2011) War as a moral imperative (not just practical politics by other means). Proceedings. Biological Sciences / The Royal Society 278(1720):2930-38.

Ginges, J., Atran, S., Medin, D. \& Shikaki, K. (2007) Sacred bounds on rational resolution of violent political conflict. Proceedings of the National Academy of Sciences of the United States of America, 104(18):7357-60.

Ginges, J., Atran, S., Sachdeva, S. \& Medin, D. (2011) Psychology out of the laboratory: The challenge of violent extremism. The American Psychologist 66(6):5019.

Kruglanski, A. W., Bélanger, J. J., Gelfand, M., Gunaratna, R., Hettiarachchi, M., Reinares, F. \& Sharvit, K. (2013) Terrorism—A (self) love story: Redirecting the significance quest can end violence. American Psychologist 68:559-75.

Marean, C. W. (2015) An evolutionary anthropological perspective on modern human origins. Annual Review of Anthropology 44:533-56.

Gómez, Á., López-Rodríguez, L., Sheikh, H., Ginges, J., Wilson, L., Waziri, H... \& Atran, S. (2017) The devoted actor's will to fight and the spiritual dimension of human conflict. Nature Human Behaviour 1(9):673-79.

Rai, T. S. \& Fiske, A. P. (2011) Moral psychology is relationship regulation: moral motives for unity, hierarchy, equality, and proportionality. Psychological Review,118(1):57-75.

Smith, D., Schlaepfer, P., Major, K., Dyble, M., Page, A. E., Thompson, J.... \& Migliano, A. B. (2017) Cooperation and the evolution of hunter-gatherer storytelling. Nature Communications 8(1853):1-9.

Sprinzak,E.(1990). The psychopolitical formation of extreme left terrorism in a democracy: The case of the Weathermen. In W. Reich (Ed.), Origins of terrorism: Psychologies, ideologies, 
theologies, states of mind (p.65-85). Cambridge,England: Cambridge University Press. 